Marusyk Yu., Klyuchkovs'ka I., 2019. "Civic activism abroad: the perspective of Ukrainian youth in the European Union", Civic activism of Ukrainian migrants in Europe: united by new challenges: Collection of materials International scientificpractical conference 24.10. L'viv: Apriori: 20-33. URL:

https://drive.google.com/file/d/1KFbZgOteQIkzJ9zsY WD8mDY_wBxQy_rh/view (in Ukrainian).
P'yatkovs'ka O., Klyuchkovs'ka I., 2019. "Partnership and cooperation of Ukrainian civic activists abroad", Civic activism of Ukrainian migrants in Europe: united by new challenges: Collection of materials International scientificpractical conference 24 .10. L'viv: Apriori: 34-43. URL:

https://drive.google.com/file/d/1 KFbZgOteQIkzJ9zsY WD8mDY_wBxQy_rh/view (in Ukrainian).

DOI: 10.26565/2220-8089-2020-37-17

УДК 327.32.019«2004/2015»

\author{
Nataliia Steblyna \\ Post-doctoral researcher \\ at Political and Government Studies Department, \\ Vasyl Stus Donetsk National University \\ 600-richchya Str., 21. Vinnytsa, Ukraine, \\ n.steblyna@donnu.edu.ua, \\ https://orcid.org/0000-0001-9799-9786
}

\title{
POLAND-UKRAINE RELATIONS IN THE DIGITAL POLITICAL DISCOURSE OF POLAND (ON THE MATERIAL OF POLISH PRESIDENT OFFICIAL WEBSITE IN 2004-2015)
}

In this study news policy of the polish president official website is regarded to be a mirror of Poland - Ukraine relations. It's assumed that it's possible to recreate the dynamics of international relations forming within both news geography analysis (comparative analysis of different countries coverage) and formal analysis of news headlines types. News from news archive of the official website of the President of the Republic of Poland were collected and content-analyzed for the dynamics of international relations recreation. With the simple qualitative comparable analysis was shown, that Ukraine was the most popular country among the post-Soviet countries (it was so even before the Euromaidan). And the change of Ukraine presidents in 2010 with radical shift of international orientations didn't reflect the intensity of attention. With the additional analysis of headlines types was shown, that for Poland Ukraine isn't only the most popular country, the contacts with it are more varied than mutual relations with other countries. It can be demonstrated with the different levels and different formats usage. In the result of comparison with Polish - Russia relations was demonstrated, that the similar approach towards seeking ways for maintain relations between the countries was used (especially before 2008), however, it was con the deficit of both attention intensity and headlines variety. In the cases of Georgia and Ukraine news policy is more formal for Georgia, more detailed and informal for Ukraine. Thus, comparative analysis of different types of headlines use shows a special, attentive and favorable attitude towards Ukraine, which don't change during Ukrainian changes of priorities in international politics and during times of crises. During the latter, Poland implements more new formats of contacts with Ukrainian politicians and appeals for wide network of international community. Meanwhile, the analysis have some limitations. It may be implemented only for countries with high number of mentions and doesn't consider the types of news and. Thus, it's may be complicated to define the essence of international relations. So, there is a need to define other formal approaches, which will help to classify texts.

Keywords: Poland - Ukraine relations, presidents' official site, news geography, digital political discourse, news policy.

(C) Steblyna N., 2020. 
Вісник ХНУ імені В. Н. Каразіна, серія «Питання політології», вип. 37, 2020

Стеблина Наталія Олександрівна

докторантка кафедри

політології та державного управління

Донецького національного університету

імені Василя Стуса

вул. 600-річчя, 21, Вінниця

n.steblyna@donnu.edu.ua,

https://orcid.org/0000-0001-9799-9786

\title{
ПОЛЬСЬКО-УКРАЇНСЬКІ ВЗАЄМОВІДНОСИНИ У ЦИФРОВОМУ \\ ПОЛІТИЧНОМУ ДИСКУРСІ ПОЛЬЩІ (НА МАТЕРІАЛІ ОФІЦІЙНОГО САЙТУ ПРЕЗИДЕНТА ПОЛЫЩІ 2004-2015)
}

\begin{abstract}
Розглядається інформаційна політика офіиійного сайту Президента Польщі, яка у иьому дослідженні сприймається як «дзеркало» польсько-украӥнських взаємовідносин. Припускається можсливість відтворення динаміки формування міжнародних взаємовідносин через аналіз географії новин (компаративний аналіз висвітлення подій у різних країнах) $i$ формальний аналіз типів новинних заголовків. Новини, зібрані з архіву англійської версії офіиійного сайту Президента Республіки Польща, стали матеріалом для контент-аналізу динаміки міжнародних взаємин. Простий кількісний компаративний аналіз показує, щзо Україна - найбільш популярна краӥна з-поміж колишніх радянських республік (так було навіть до Свромайдану). I зміна українських президентів у 2010 роиі з радикальною зміною міжнародних орієнтацій (i проєвропейського курсу - на проросійський) не відбилася на інтенсивності уваги на сайті. На основі формального аналізу доводиться, що для Польщі Украйна - не тільки найбільш популярна країна, але контакти з нею відбуваються в різній кількості форматів та рівнів. Порівняння із польсько-російськими взаєминами показує деяку схожість між краӥнами (особливо до 2008), хоча все ж очевидним є дефіцит уваги та різноманіття заголовків для Росії. Відзначається, щяо у випадку з Грузією та Украӥною, новинна політика більш формальна для Грузї, більш деталізована та неформальна - для України. Таким чином, внаслідок компаративного аналізу різних типів заголовків продемонстроване особливе, уважне $i$ доброзичливе ставлення до України, яке не змінювалося, незважаючи на зміну зовнішньої політики України під час кризи. Підкреслюється, щзо під час кризи Республіка Польща встановлювала нові формати для взаємодії із украӥнськими політиками й активно апелювала до підтримки міжнародної спільноти. Звертається увага на деяку обмеженість компаративного аналізу, оскільки його можна застосовувати тільки для країн із великою кількістю згадок у 3МI, $і$ він не враховує тип новин. Це позначається на повноті окреслення суті міжнародних взаємин. Робиться висновок про необхідність визначення й інших формальних підходів, які допоможуть класифікувати політичні тексти.

Ключові слова: Польсько-Украйнські взаємини, офічійний сайт президента, географія новин, ичифровий політичний дискурс, інформачійна політика.
\end{abstract}

Стеблина Наталия Александровна докторантка кафедры политологии и государственного управления Донецкого национального университета имени Василия Стуса ул. 600-летия, 21, Винница n.steblyna@donnu.edu.ua

https://orcid.org/0000-0001-9799-9786

\section{ПОЛЬСКО-УКРАИНСКИЕ ОТНОШЕНИЯ В ЦИФРОВОМ ПОЛИТИЧЕСКОМ ДИСКУРСЕ ПОЛЬШИ (НА МАТЕРИАЛЕ ОФИЦИАЛЬНОГО САЙТА ПРЕЗИДЕНТА ПОЛЬШИ 2004-2015)}

Рассматривается информационная политика официального сайта Президента Польши, которая в этом исследовании воспринимается как «зеркало» Польско-Украинских 
отнотений. Допускается возможность воссоздания динамики формирования международных отношений через анализ новостной географии (компаративный анализ освещения событий в разных странах) и формальный анализ типов новостных заголовков. Новости, собранные из архива английской версии официального сайта Президента Республики Польша, стали материалом для контент-анализа. С его помощью воссоздавалась динамика международных отношений. Простой количественный компаративный анализ показывает, что Украина - наиболее популярная страна среди бывиих советских республик (так было даже до Евромайдана). И смена украинских президентов в 2010 году с радикальным изменением международных ориентащий (и проевропейского курса - на пророссийский) не отразилась на интенсивности внимания на сайте. На основе формального анализа доказывается, что для Польши Украина не только самая популярная страна, но контакты с ней производятся в разнообразном количестве форматов и уровней. Сравнение с Польско-Российскими отношениями показывает некое сходство в процессе установления отночений между странами (особенно до 2008), хотя все же очевидным является дефииит внимания и разнообразия заголовков для России. Компаративный анализ новостной политики по Грузии и Украине, показывает более формальное отнотение для Грузии и более детализированное и неформальное внимание - для Украины. Сравнение разных типов заголовков показывает особое, внимательное и доброжелательное отночение к Украине, которое не изменялось, несмотря на смену внешней политики Украины и во времена кризиса. Подчеркивается, что во время кризиса Республика Польша устанавливала новые формать для взаимодействия с украинскими политиками и активно апеллировала $к$ поддержке международного сообщества. Обращается внимание на некоторые ограничения анализа. Его можно применять только для стран с большим количеством упоминаний, и анализ не учитывает тип новостей. Это отражается на полноте описания сути международных отнотений. Делается вывод о необходимости определения и других формальных подходов, которые помогут классифииировать политические тексты.

Ключевые слова: Польско-Украинские отночения, официальный сайт президента, география новостей, ичифровой политический дискурс, информационная политика.

The first snapshot of the Polish President official website was made by web archive on 12 th of December, and the site already had a page «Co nowego» (What's new?) with current news and news archive Wayback Machine. Using the latter, one may find the first news item about Ukraine on $18^{\text {th }}$ of March 1997 «Spotkanie Prezydenta RR z Premierem Ukrainy» (Meeting of RP President with Ukrainian Premier Minister).

Both communication and international relations scholars rarely study presidents' sites to consider international relations. In the field of communications news of mass media are usually taken into consideration, and within the approach of «news flow» specifics of international journalism and news dissemination are usually discovered. Official sites are used as a material for users' interactions or behavior analysis (Lin, Cho 2010), for effectively of promotion valuation (Mabry, Porter 2010), discourse analysis of places representation in tourism sphere (Hallett, Kaplan-Weinger 2010) and city's images (Díaz-Luque 2009). However, news content on an official site usually perceived as something secondary and insignificant.
Online activity of presidents or states' officials is also actively studied, however, not news on an official presidential site are used, but social networks posts, especially, Donald Trump's ones (Ott 2017; Cappelletti 2019;McGranahan 2019; Pérez-Curiel, Naharro 2019; Schneiker 2019).

As for international relations, a president's speeches or decrees (tweets nowadays) are the most common material for research.

However, study of news policy of a president's or a politician's official website allows a researcher to get more complete picture of both digital political discourse and official activity (as a rule, visits, statements, decrees and etc. are displayed in news). In the times of speed culture, when journalists haven't enough time for information collecting and processing, news from an official site are frequently reprinted, thus it's possible to discover the influence of official discourse on mass media content and to calculate the percent of so-called «press releasm» (mass media news, written on the bases of press releases). Additionally, news are suitable for formal analysis, thus it's possible to study large massive of data.

In this study news policy of the polish president official website is regarded to be a mirror of Poland - Ukraine relations. It's 
assumed that it's possible to recreate the dynamics of international relations forming within both news geography analysis (comparative analysis of different countries coverage) and formal analysis of news headlines types. Being «Ukrainian advocate in Europe», Poland have been paying great attention to Ukrainian issues, however, Ukrainian presidents (Yuschenko and Yanukovych) demonstrated quite different approaches to international policy. This fact, as well as, Euromaidan and Russian aggression, might have influenced the character of news coverage on the Polish president official website.

One more point, which should be taken into consideration, is the dynamic character of online news as a text. At first, online news were just a copy of off line practices (communique or official chronicle in the case of a president official website). These texts were not addressed to the mass audience, were written with strict and unexpressive manner didn't contain links or multimedia. Nowadays official sites are pretending to be a direct channel of communication with wide audiences and implement new techniques of writing and texts presenting.

Thus, in the paper news from the Polish President official website between 2004-2015 will be studied in order to distinguish the reflection of Poland - Ukraine relations in comparison with other post-Soviet countries.

Poland - Ukrainian relations in 21th century

There is some consensus among Polish and Ukrainian scholars about Poland - Ukraine relations in 21th century being strategic ones, where the countries value independence of each other and orient towards cooperation. As far as European Ukraine is important for Poland, it's constantly working on Ukrainian European and NATO integration, and the country is among the most active lobbyists of this possible future unity (Reznikov, Elfimova 2017: 73). Poland is perceived to be Ukraine's European and international structures «guide» (Evsyukova 2013: 70)and one of Ukraine's best friends in Europe (International Centre for Policy Studies 2018: 4).

There are several causes for this: Polish wish to have safe neighborhood and some Polish ambitions for achieving leadership in Central and Eastern Europe. In the whole region Poland stimulates «regional cooperation» and «democratic transition and integration» (Celewicz \& Niziol-Celewicz, 2006: 223) and «consider itself as somehow responsible for the
EU's eastern neighbors» (Iwaniuk 2017). Ukrainian European intentions are perceived in Poland as its' own, not only Ukrainian strategic interest (Evsyukova 2013: 68). With the stable, European Ukraine there wouldn't be such dangers as «civil war on the other side of the border, development of organized crime or arrival of waves of refugees from Ukraine» (Szeptycki 2016: 63). With its' help to Ukraine, Poland may gain the favorable role within the EU and internationally (Szeptycki 2016: 64).

There are several positions about events, which led to the maintaining of more open and friendly relations between two countries after the states gain independence. Chorna considers mid 90-th (the beginning of the first Kuchma presidential term) to be important for strategic role of mutual contacts afterwards (Chorna 2016: 32; Draus 2011: 59). Barwinski regarded Orange revolution (2004-2005) to be «the turning point» of «mutual prejudices and stereotypes» overcoming (Barwiński 2013: 12). The period between 2005 - 2012 scholars characterize as a period of stabilization of mutual relations (Evsyukova 2013: 71). There are some contradictable statements about Yanukovych presidency and Poland - Ukraine relations. Barwinski called the relations just «appropriate» (Barwiński 2013: 12). Whereas Fesenko constitutes the existence of consensus about strategic character of mutual relations, thus even personalities of presidents or their political orientations don't influence this consensus (Tarasenko 2015). And Polish support during Yanukovych term, which was the period of pro-Russian orientation, remained active (International Centre for Policy Studies, 2018: 4). Thus, additional study of the period is important to understand Polish - Ukraine relations in the times of priority changes, in other words, what did Ukrainian pro-Russian orientation during Yanukovych presidency mean for the relations?

Meanwhile there are considerable reasons for constructive and stable relations between the two countries: internal development of both countries societies, world's conjuncture, and leading Western states influence (Evsyukova 2013: 73); common border and traditional interrelations, for instance in agricultural sector (Chorna 2016: 31). However, since Poland joined the EU, the need for structure and content modernization of political dialogue have been becoming more actual, due to both political and economic differences between two countries (Reznikov, Elfimova 2017: 73). In the times of Yuschenko and afterwards several «symbolic acts of reconciliation... and joint 
actions in the international arena, economic projects and sports events» (Barwiński 2013: 12-13) were held. So it's important to discover the character of contacts between the countries, in particular, the balance between traditional and new formats of interaction.

\section{Material and method}

News from news archive of the official website of the President of the Republic of Poland (https://www.prezydent.pl/en/archive/) were collected and content-analyzed for news geography recreation. English version of the site was used, as far as possible audiences of the news from post-Soviet and other countries may explore this, not Polish, version more frequently.

With the help of «search option» news items with names of countries as well as geographical names and names of post-Soviet officials in headlines and first sentences were picked. After that news about the post-Soviet countries were categorized for each year between 2004-2015. Within each category news items were:

- calculated (to define countries, which were mentioned more frequently and constantly);

- differentiated into three types (formal, formal detailed, informal) and the ratio of headlines types was studied for each country.

\section{Formal, formal detailed and informal headlines}

Due to the review of all the headlines, it's possible to note the progressive transformation of communique-style headlines to mass-media style. The communique-style headlines were used on the site until 2009, from 2010 massmedia style has been become to prevail. Additionally, news from Poland's leading information agency - PAP - were added to the own information. Despite of this fact, it's possible to sort all the headlines into three groups: formal, formal detailed and informal.

In the communique-style formal headlines positions, the type of visit or type of conversation and sometimes condolences on some tragic events or congratulations are mentioned. The fact of meeting or visit is just stated, emotions, quotes or expression aren't used. For instance:

- Official visit by the President of the Republic of Poland to the Republic of Lithuania

- Condolences from the President of the Russian Federation

In mass media-style formal headlines there is the same unemotional stylistic and just fact's statement. However, the narration is simplified:

- President of Russia in Poland

- President congratulates Poroshenko
- President sends condolences to Russia

- Phone conversation with the president of Ukraine

However, it's possible to formalize such headlines collection, as far as the headlines contain:

- official (President of the Republic of Poland) or simplified (Komorowski) names of presidents sometimes with mention of presidents spouse;

- names of states or states' capitals (the Republic of Lithuania or Vilnius);

- certain phrases (official visit, telegram of congratulations, telephone conversation, meeting between - for communique-style formal texts) or certain verbs (visit, talk, congratulate, send and neutral synonyms).

It's important to mention, that in the formalized headlines special circumstances of an event aren't specified, while constant formats for mutual contacts are used. As far as formalized headlines reflect only obligatory actions for relations between countries, thus, with the help of such texts it's possible to define countries, which just set diplomatic relations with Poland. And if there is only formalized headlines are mentioned, it means, that there is not some mutual intentions towards rapprochement.

Meanwhile, if the special circumstances or place (not just a capital or name of a country) are specified, it means that the relations between two states are more deep and countries create special occasions for contacts. Thus, it's possible to define formal detailed headlines, which contain:

- Format of event or special place (Ceremonial Opening and Consecration of the Lvov Eaglets Cemetery);

- Names of other officials, not only a president (Minister of the Interior of Azerbaijan);

- Neutral statements, joint or separate (Common positions of Presidents of Poland, Lithuania and Ukraine or President on the Message of Polish and Russian churches).

All the headlines of this group are neutral and differentiates from the formal group only with the mentioning of some details. In journalism such details are used to attract attention towards a news item. Moreover, the fact of such type of headlines emergence and prevalence testifies the mass media professionalization of official discourse and it potential for direct interaction with audiences (without mass media). 
Whereas the last group of headlines is expressive and contains direct or indirect quotes, it displays attitudes. It's possible to define it with the help of quotation marks, colon and verbs, which express attitudes, and adjectives:

- Polish - Lithuanian relations are excellent;

- Russia is not an easy partner;

- Poland supports Georgia's membership of NATO;

- President: Azerbaijan may significantly influence European energy security.

Special statements on some significant (usually crisis events) were also added to this group (Statement of the Chancellery of the
President of RP in connection with the situation in Georgia).

Such headlines demonstrate intentions of Polish official to influence the relationship with a country with the help of appeals or statements. Thus, the prevalence of formal ones will testify intentions to use traditional formats and institutes in mutual relations; formal detailed headlines will give evidences for seeking new formats of interactions. And, informal headlines points on special occasions, when words matter more that actions.

News geography of post-Soviet countries

As we can see in the Table 1, Ukraine is among top-mentioned post-Soviet countries.

Mentions about post-Soviet countries on the official website of the President of the Republic of Poland

\begin{tabular}{|c|c|c|c|c|c|c|c|c|c|c|c|c|c|c|c|}
\hline & UA & LT & RU & GE & EE & LV & AZ & MD & BY & AM & KZ & KG & UZ & $\begin{array}{l}\text { Tot. } \\
\text { countr. }\end{array}$ & $\begin{array}{l}\text { Total } \\
\text { num. } \\
\text { of } \\
\text { news }\end{array}$ \\
\hline 2004 & 5 & 0 & 1 & 0 & 0 & 0 & 0 & 0 & 0 & 0 & 0 & 0 & 1 & 7 & 50 \\
\hline 2005 & 5 & 1 & 2 & 1 & 1 & 1 & 1 & 0 & 0 & 0 & 0 & 0 & 0 & 12 & 85 \\
\hline 2006 & 14 & 15 & 7 & 1 & 0 & 0 & 0 & 1 & 0 & 0 & 2 & 0 & 0 & 40 & 186 \\
\hline 2007 & 11 & 11 & 3 & 5 & 5 & 0 & 3 & 0 & 0 & 0 & 1 & 0 & 0 & 39 & 149 \\
\hline 2008 & 14 & 9 & 6 & 18 & 3 & 1 & 6 & 0 & 1 & 0 & 0 & 1 & 0 & 59 & 88 \\
\hline 2009 & 5 & 6 & 0 & 3 & 2 & 1 & 1 & 0 & 0 & 0 & 0 & 0 & 0 & 18 & 114 \\
\hline 2010 & 4 & 5 & 5 & 1 & 1 & 1 & 0 & 1 & 1 & 1 & 0 & 0 & 0 & 20 & 84 \\
\hline 2011 & 7 & 4 & 4 & 2 & 3 & 2 & 1 & 1 & 1 & 1 & 0 & 0 & 0 & 26 & 74 \\
\hline 2012 & 18 & 1 & 5 & 1 & 2 & 6 & 0 & 3 & 1 & 0 & 0 & 0 & 0 & 37 & 163 \\
\hline 2013 & 23 & 4 & 4 & 1 & 0 & 2 & 0 & 1 & 0 & 1 & 0 & 0 & 0 & 36 & 152 \\
\hline 2014 & 57 & 3 & 8 & 3 & 2 & 1 & 0 & 3 & 0 & 0 & 0 & 0 & 0 & 77 & 199 \\
\hline 2015 & 33 & 2 & 9 & 1 & 2 & 2 & 0 & 0 & 5 & 0 & 0 & 0 & 0 & 54 & 221 \\
\hline Tot. & $\underline{196}$ & $\underline{61}$ & $\underline{54}$ & $\underline{37}$ & $\underline{21}$ & $\underline{17}$ & $\underline{12}$ & $\underline{10}$ & $\underline{9}$ & $\underline{3}$ & $\underline{3}$ & $\underline{1}$ & $\underline{1}$ & $\underline{425}$ & $\underline{1481}$ \\
\hline
\end{tabular}

Thus, there were only four years, when Ukraine wasn't in the top of the site's attention. In 2008, it was Georgia, because of the RussianGeorgian war. In 2006-2007 Lithuania was mentioned quite frequently, but the leading topic of the news was friendship between the two countries. In 2010, it was Russia, here air crash near Smolensk may be an explanation, however. Komorovsky's intentions to maintain relations with Medvedev should be mentioned as well.

It's also remarkable, that attention to Ukraine began to grow from 2011-2012 - two years before the Euromaidan and with the beginning of Yanukovych term (See also the growth of trade between the two countries

Table. 1 
define the types of coverage for the post-Soviet countries and to describe the case of Ukraine. But, the small number of mentions could be an argument for more formal and distant relations. For instance, two post-Soviet countries aren't in the list (Tajikistan and Turkmenistan). Two more Central Asian countries (Kirgizia and Uzbekistan) mentioned only once. Remarkable, that Tulip revolution in Kirgizia (2005) wasn't included in the news feed of the site, however, Ukrainian Orange revolution was displayed in four news items. "0" mentions of Russia in 2009 is also a remarkable fact of deterioration of relationshipafter the Russian-Georgian war.

The specifics of mutual relations in headlines about Ukraine, Lithuania, Russia and Georgia

In the Table 2 let's see the headlines distribution in news about the most popular countries, where $\mathrm{f}$ - formal, f/d - formal detailed, I - informal headlines.

The types of headlines about the most popular countries on the official site

Table 2 of the President of Poland

\begin{tabular}{|r|r|r|r|r|r|r|r|r|r|r|r|r|r|}
\hline & \multicolumn{4}{l|}{ Ukraine } & \multicolumn{4}{l|}{ Lithuania } & \multicolumn{3}{l|}{ Russia } & \multicolumn{2}{|l|}{ Georgia } \\
\hline & $f$ & $f / d$ & $i$ & $f$ & $f / d$ & $i$ & $f$ & $f / d$ & $i$ & $f$ & $f / d$ & $i$ \\
\hline 2004 & 1 & 3 & 1 & 0 & 0 & 0 & 1 & 0 & 0 & 0 & 0 & 0 \\
\hline 2005 & 4 & 1 & 0 & 1 & 0 & 0 & 2 & 0 & 0 & 0 & 0 & 1 \\
\hline 2006 & 3 & 3 & 8 & 5 & 4 & 6 & 0 & 1 & 6 & 1 & 0 & 0 \\
\hline 2007 & 7 & 3 & 1 & 7 & 3 & 1 & 2 & 0 & 1 & 5 & 0 & 0 \\
\hline 2008 & 10 & 2 & 2 & 5 & 4 & 0 & 3 & 2 & 1 & 11 & 2 & 5 \\
\hline 2009 & 1 & 0 & 4 & 1 & 1 & 4 & 0 & 0 & 0 & 0 & 1 & 2 \\
\hline 2010 & 2 & 1 & 1 & 3 & 0 & 2 & 2 & 2 & 1 & 0 & 1 & 0 \\
\hline 2011 & 4 & 3 & 0 & 2 & 2 & 0 & 0 & 3 & 1 & 2 & 0 & 0 \\
\hline 2012 & 2 & 13 & 3 & 0 & 0 & 1 & 1 & 3 & 1 & 1 & 0 & 0 \\
\hline 2013 & 0 & 15 & 8 & 0 & 2 & 2 & 1 & 3 & 0 & 0 & 1 & 0 \\
\hline 2014 & 6 & 31 & 20 & 1 & 0 & 2 & 1 & 4 & 3 & 0 & 1 & 2 \\
\hline 2015 & 4 & 22 & 7 & 0 & 2 & 0 & 0 & 4 & 5 & 0 & 1 & 0 \\
\hline total & 44 & 97 & 55 & 25 & 18 & 18 & 13 & 22 & 19 & 20 & 7 & 10 \\
\hline
\end{tabular}

Poland - Ukraine - Lithuania

These two countries have got the largest number of mentions, however, their character differs. In the case of Lithuania, formal headlines prevail.

It's remarkable, that contacts between Poland and Lithuania were more intense 2006 2008, and afterwards the attention to the country became low (some mutual tensions may be the reason, See (Barwiński 2013). We have the same situation with Ukraine (more intense contacts between 2006-2008 and low attention in 2009-2010), however, it was an increase of attention since 2011 .

As for the balance between formal, formal detailed and informal headlines - it's also looks alike. In 2007-2008 both countries have intense meetings and communication on several levels (higher presidential and lower official) and in several formats (constant and inconstant) with Poland. And informal headlines are the most popular in 2006 in both countries.

\section{Poland - Ukraine - Russia}

In 2006, as well as in the cases of Ukraine and Lithuania, we can see Polish intentions to liven relations with Russia ${ }^{1}$, despite of antiPoland rhetoric in the country after the Orange revolution (See (Celewicz, Niziol-Celewicz, 2006)).However, afterwards there was spasmodic character of Russia mentions in 2007-2010. It's also remarkable, that informal mentions led to significant increase in both formal and formal detailed headlines in Ukraine (17 (f), 5(f/d) - for two years) and in Lithuania (12 (f), 7 (f/d)). And the countries in 2006 informal mentions were accompanied with both formal and formal detailed headlines. However, we see the different picture in Russia: only 1 formal detailed text and lower number of mentions in 2007-2008. As for mentions in 2008

\footnotetext{
${ }^{1}$ it's remarkable, that the first headline about this was "Russia is not an easy partner"
} 
and 2010, unplanned (or in journalism terms breaking) news should be taken into account ${ }^{1}$. As for similarities between Russia and Ukraine, the prevalence of formal detailed headlines should be noticed. For both countries we see Poland's intentions of constant intentions to contact with the countries or to apply to international community on the countries' issues (as for Russia, it was appeals about sanctions and Russian aggression). Whereas, Polish interest towards Ukraine is much more expressive, and pro-Russian orientation of the country in the times of Yanukovych didn't affect this.

\section{Poland - Ukraine - Georgia}

Poland's interest towards Georgia almost not go beyond 2007-2008. And, it's more formal in headlines (like in Lithuania case). In 2007-2008 there were intense formal contacts (visits, meetings, telephone conversations). Here it's interesting to compare the official website's reflection of Russian invasion into Georgia in 2008 (with Poland's intention to solve it with traditional approaches) and Russian aggression towards Ukraine in 2014 - 2015 (with prevalence of formal detailed and informal headlines).

And despite of Georgia's pro-European orientation during Saakashvili's term, there wasn't such intense interest in this country comparable to Ukraine in the times of Yuschenko, for instance. We see the decrease in Polish interest towards Georgia after 2008 with 1-3 mentions per year. Whereas the growth of formal and especially formal detailed and informal headlines about Ukraine comparably to three other countries testifies Polish intense intentions to create special occasions to contact with Ukraine in the times of pro-Russian orientation of the state's government.

\section{Conclusions}

News policy of the official website of the president of Poland confirms constant and intense approaches towards communication with Ukraine. Thus, news geography of the site differs from the traditional approach of mass media, where core countries displayed more frequently and more favorably. This means, that this parameter is worth further studying, as well as news policy on official presidential sites.

\footnotetext{
${ }^{1}$ Death of Solzhenitsyn and Alexy II, the Patriarch of Moscow and all Russia in 2008, air crash near Smolensk in 2010. It's also remarkable, that in 2008 Kaczynski congratulated Medvedev twice (on his assumption of the office of President of the Russian Federation (8 of May) and on his election (4 of March).
}

The simple qualitative comparable analysis shows, that Ukraine was the most popular country among the post-Soviet countries (it was so even before the Euromaidan). There were no periods of salience with no or minimal mentions (comparable with other top-popular countries, like Lithuania, Russia, Georgia, Estonia and Latvia. And the change of Ukraine presidents in 2010 with radical shift of international orientations didn't reflect the intensity of attention. Moreover, it became to increase. Of course, the worldwide tendency of data growth should be taken into account, however, comparative analysis didn't show the same increase of other post-Soviet countries mentions.

The additional analysis of headlines types shows, that for Poland Ukraine isn't only the most popular country, the contacts with it are more varied than mutual relations with other countries. It can be seen on different levels and in different formats. And, crisis times only intensify this tendency. The approach to design intense and friendly relations on high presidential and lower official levels, in formats of common statements, consultations, round tables, commemorations is seen during Yuschenko term (and here we see some similarities between Polish - Lithuanian relations).

Comparison with Polish - Russia relations shows as the similar approach towards seeking ways for maintain relations between the countries (especially before 2008), however, it's possible to see the deficit of both attention intensity and headlines variety. Thus, it's possible to conclude, that constant activity in all three dimensions (traditional forms, new formats designing and statements) is needed.

In the cases of Georgia and Ukraine, we also see, that conflicts with Russia don't cause the same reaction (more formal for Georgia, more detailed and informal for Ukraine). And the simple mentions count shows that pro-Euro intentions of Georgia aren't displayed with the same intensity as Ukraine ones (and data of Moldovan headlines confirms this as well; Moldova has its tensions with Russia as well, however, not in the hot phase, and has the border with Poland, but it's only number 7 on popularity).

To sum up, comparative analysis of different types of headlines use shows a special, attentive and favorable attitude towards Ukraine, which don't change during Ukrainian changes of priorities in international politics and during times of crises. During the latter, Poland implements more new formats of contacts with 
Ukrainian politicians (opposition as well - its also the unique example within the post-Soviet territory) and appeals for wide network of international community. During Duda's presidency, both intensity and character of mentions about Ukraine have been decreasing and need further discoveries.

\section{Discussion}

Formal methods for political international communication analysis are in deep need during the times of information overflow and big data. Whereas official sources provide big amounts of messages, which may be collected and analyzed with the help of machine methods.

The simple qualitative comparative analysis of news geography on official presidents' site is convenient method for rapid formalized information collection and processing for large periods. It's possible to define the most popular countries, the character of attention (constant, spasmodic or inconstant). And, spasmodic attention with significant differentials seems to be extremely interesting for further scientific discoveries in international relations, especially in the digital times, with unpredictable growth of information. It's also interesting to investigate character of mentions in the crisis times, when we see the increase of attention not only towards the country, which faces it, but towards other states, which may be regarded as partners or as rivals.

Meanwhile, the analysis have some limitations. It may be implemented only for countries with high number of mentions and doesn't consider the types of news and. Thus, it's may be complicated to define the essence of international relations. Therefore, there is a need to define other formal approaches, which will help to classify texts. Analysis of headlines types (formal, formal detailed, informal) gives us a possibility to define variety of contacts between countries and to evaluate the level of communication emotionality (according to this research data, there was significant growth of formal detailed and informal headlines since 2012 - before the Euromaidan. For the further discoveries, more types of headlines may be added: for instance braking news and scheduled ones. This will help to exclude headlines about unplanned events from formal and formal detailed types and, as a result, will make planned official intentions more salient.

One more observation is about changes in the character of communication in 2010. It's possible to note the growth of number of news on the official site and the style of news writing. Thus, it's interesting to seek similar tendencies on official sites of other presidents and to compare tendency towards the level of emotionality increasing. These tendencies may be interrelated because of communication strategies transformation from indirect contact with audiences (with mass media involving till 2010) to direct (without mass media). The possibility of direct communication with mass audience may change not only the standards of news writing, but all the strategies of political international communication.

\section{REFERENCES}

Lin, J. S., Cho, C. H. 2010. "Antecedents and Consequences of Cross-Media Usage: A Study of a TV Program's Official Web Site". Journal of Broadcasting \& Electronic Media 54: 316-336.

Mabry, E., Porter, L. 2010. "Movies and MySpace: The Effectiveness of Official Web Sites versus Online Promotional Contests". Journal of Interactive Advertising 10(2): 1-15.

Hallett, R. W., Kaplan-Weinger, J., 2010. Official Tourism Websites: a Discourse Analysis Perspective. Bristol: Channel View Publications.

Díaz-Luque, P. 2009. "Official Tourism Web Sites and City Marketing". In: Information Communication Technologies and City Marketing: Digital Opportunities for Cities around the World. Hershey: InformatIonScIence Reference 152-183.

Ott, B. L. 2017. "The age of Twitter: Donald J. Trump and the Politics of Debasement". Critical Studies in Media Communication 34(1): 59-68.

Cappelletti, A. 2019. "Between Centrality and Re-scaled Identity: A New Role for the Chinese State in Shaping China's Image Abroad: The Case of the Twitter Account". Chin. Polit. Sci. Rev. 4(3): 349-374.

McGranahan, C. 2019. "A Presidential Archive of Lies: Racism, Twitter, and a History of the Present". International Journal of Communication13: 3164-3182.

Pérez-Curiel, C., Naharro, P. L. 2019. "Political Influencers. A study of Donald Trump's Personal Brand on Twitter and Its Impact on the Media and Users". Comunicacion y Sociedad 32(1): 57-76.

Schneiker, A. 2019. "Telling the Story of the Superhero and the Anti-Politician as President: Donald Trump's Branding on Twitter'. Political Studies Review 17(3): 210-223.

Reznikov, V., Elfimova Yu. 2017. "Ukraine and Republic of Poland Cooperation: Economy and Diplomacy aspect". World economy and international economic relations 3: 72-78.

Evsyukova, O. 2013. "Ukraine and Poland: Common Strategic Priorities in the Process of Historical Transformations". Investments: Practice and Experience 1: 68-73.

International Centre for Policy Studies, 2018. Ukraine-Poland Relations, Kyiv.

Celewicz, M., Niziol-Celewicz, M. 2006. "Relations between Poland and its Eastern 
Neighbours after the 1999 NATO Enlargement". UNISCI Discussion Papers 10: 221-245.

Iwaniuk, O. 2017. "Poland-Ukraine relations: The Ball is in Your Court". New Eastern Europe. URL:

https://neweasterneurope.eu/2017/10/31/poland-

ukraine-relations-ball-court/

Szeptycki, A., 2016. "Poland-Ukrainian Relations". UNISCI Journal 57-66.

Chorna, N., 2016. "Ukrainian-Polish Economic Cooperation". International Trade: Economy, Finance, Law 2: 31-41.

Draus, J. 2011. "Polish-Ukrainian Relations after Independence". NEW UKRAINE 11: 55-72.
Barwiński, M. 2013. "Polish Interstate Relations with Ukraine, Belarus and Lithuania After 1990 in the Context of the Situation of National Minorities". European Spatial Research and Policy 20(1): 5-26.

Tarasenko, N. 2015. "Perspectives of Ukraine and Poland Relations in the Context of Activity of Newly Elected Polish President A. Duda".Social Communications Research Center. URL: http://nbuviap.gov.ua/index.php?option=com_conten t\&view=article\&id=1227:ukrajinsko-polskividnosini $-2 \&$ catid $=63 \&$ Itemid $=393$
Рагімлі Мубаріз

аспірант кафедри політології,

Харківський національний університет імені В.Н. Каразіна, майдан Свободи, 4, Харків, 61022, rahimlimubariz@gmail.com, https://orcid.org/0000-0001-5999-1062

\section{ЄВРОПЕЙСЬКИЙ АСПЕКТ ЗОВНІШНЬОЇ ПОЛІТИКИ АЗЕРБАЙДЖАНУ}

Розглянуто стан та етапи проиесу розбудови державності Азербайджанської Республіки, особливості якого зумовлені специффікою історії, географічними, геополітичними, національно-культурними факторами. Висвітлюється роль національної держави як єдино можливого політичного інституту, який спроможний відстоювати національні інтереси як всередині країни (в економічній, соціокультурній, внутріполітичній сферах), так $i$ на міжнародній арені. Підкреслюється зростаюча роль сучасної держави у збереженні свого суверенітету в епоху формування багатополярного постглобалізаційного світу та в ефективному використанні власних природних та інших ресурсів на благо громадян своєї краӥни. Особлива увага приділяється взаєминам Азербайджану як однієї з краӥн Південного Кавказу з потужними геополітичними акторами, зокрема с Свропейським Союзом. Вказується на наявність нерозв'язаної проблеми тривалого армяно-азербайджанського конфлікту, що $\epsilon$ загрозою національному суверенітету Азербайджану. Пояснюється специфіка відносин Азербайджану з Свросоюзом, а саме, з одного боку, значимість АР як краӥни-транзитера й постачальника газонафтових ресурсів Каспійського басейну для ЄС, а з іншого - постійний тиск на політичне керівництво Азербайджану з метою змусити запроваджувати структурні політичні зміни та неухильно виконувати загальноприйняті у Західній Європі демократичні принципи та цінності. Підкреслюється поступова трансформація політики самого Євросоюзу у сенсі більшої наближеності до реалістичної очінки свойх відносин з краӥнами-членами, краӥнами-сусідами та асоційованими членами.

Ключові слова: Азербайджан, Свросоюз, глобалізачія, посталобалізація, економічна криза, суверенітет, зовнішня політика.

(C) Рагімлі М., 2020. 